\title{
3.2 Кримінальні покарання та заохочення як парні правові категорії: гносеологічний аспект
}

Права і свободи людини та їх гарантії, - наголошується у ст. 3 Конституції України, - визначають зміст і спрямованість діяльності держави. Держава відповідає перед людиною за свою діяльність. Утвердження і забезпечення прав i свобод людини $є$ головним обов'язком держави [85]. Юридична відповідальність відіграє значну роль серед правових заходів, безпосередньо покликаних сприяти реалізації конституційного обов'язку держави. Суспільна цінність відповідальності обумовлюється ії̈ подвійною правовою природою: 3 одного боку, це основний захід державного впливу, що забезпечує реалізацію законодавства, з іншого, - гарантує всім суб'єктам права безумовну реалізацію ïx законних прав i свобод, поновлює їх у разі порушення. Кримінальна відповідальності безпосередньо пов'язана 3 таким функціями держави як створення і підтримання правопорядку, всебічна реалізація прав і свобод особи, стимулювання правомірної поведінки громадян. Правомірна поведінка $\epsilon$ головною метою у кримінально-правовому регулюванні, де на першому місці знаходиться кримінально-правова норма, що містить правову вимогу (заборону чи дозвіл) та суб’єкт кримінально-правового відношення, - iї адресат людина, спроможна усвідомити вимогу закону та співвіднести із нею свою поведінку. Кримінально-правова норма зумовлює необхідність відповідної реакції держави на вчинення як протиправної, так і правомірної поведінки, по-перше, тому, що так зобов'язує суспільна необхідність та, по-друге, тому, що цього потребує й природа позитивного права.

Кримінальна відповідальність є важливим засобом регулювання (охорони) суспільних відносин, сутність якого полягає у цілеспрямованому впливі на поведінку особи за допомогою правових засобів, 3 метою упорядкування суспільних відносин, надання їм системності й стабільності, уникнення соціальних конфліктів, втілення соціальної справедливості, цивілізованості та високої правової культури суспільства. В сучасних умовах реалізація принципу невідворотності кримінальної відповідальності й покарання зазнає раціональної 
модифікації. До механізму кримінально-правового регулювання залучаються засоби, засновані на стимулюванні правомірної, суспільно-корисної поведінки. Слід прогнозувати, що сфера їх застосування буде розширюватися, що $\epsilon$ природнім об'єктивним процесом, зумовленим не тільки неоднорідністю та складністю правового регулювання, але й гуманізацією всіх сторін суспільного життя [86, с. 363-364]. Так, тенденцією останніх років є значна кількість осіб, які здебільшого вперше вчинили злочини невеликої та середньої тяжкості, та до яких біло застосовано заохочення у вигляді звільнені від кримінальної відповідальності у разі здійснення ними відповідного комплексу правомірної суспільно-корисної поведінки. За останні п’ять років кількість звільнених від кримінальної відповідальності відповідно складала: у зв’язку з дійовим каяттям (ст. 45 КК) в 2015 р. - 1263, 2016 р. - 1072, 2017 p. - 1420, 2018 p. - 1811, 2019 p. - 1914 осіб; у зв’язку з примиренням винного з потерпілим (ст. 46 КК) в 2015 р. -3143, 2016 р. - 2902, 2017 р. - 3010, 2018 р. - 2980, 2019 р. - 3347 осіб; у зв’язку 3 передачею особи на поруки (ст. 47 КК) в 2015 р. - 630, 2016 р. - 457, 2017 p. 428, 2018 р. - 367, 2019 р. - 375 осіб; у зв’язку із зміною обстановки (ст. 48 КК) в 2015 p. $-865,2016$ p. - 601, 2017 p. - 422, 2018 p. - 471, 2019 p. - 466 осіб [87, c. 50-52].

Реалізація принципів гуманізму, економії кримінальних засобів примусу об’єктивно зумовлює появу норм, які заохочують, стимулюють осіб, що потрапили у сферу кримінально-правового регулювання, вчиняти правомірні, соціально-корисні діяння, загалом поводитися як законослухняні громадяни. Закон повинен гарантувати громадянам суб'єктивне право самостійно протидіяти суспільно-небезпечним та злочинним нападам, а у випадку вчинення особою злочину, - покаятися, спокутувати свою провину перед потерпілим, суспільством і державою позитивної поведінкою у виді добровільного повідомлення про вчинене, дійового каяття, примирення 3 потерпілим, здачі суспільно-небезпечних предметів та засобів, сприяння розкриттю вчиненого злочину та інше. Кримінально-правове забезпечення цього суб'єктивного права є важливою правовою гарантією дотримання прав і свобод людини в сучасному 
українському суспільстві. Заохочення, як різновид кримінально-правових заходів, визнаний більшістю вченими-правниками знайшов реалізацію саме в кримінальному праві у вигляді заохочувальних норм [88, с. 162-163].

Віддзеркалення складної взаємодії негативного та позитивного аспектів кримінальної відповідальності окреслюється не тільки виключно проблемним характером, а й має інноваційне значення для сучасної юридичної науки й для теорії кримінального права, зокрема. «Наукові юридичні поняття і категорії, вказує В.М. Селіванов, - як форми відображення, опосередкування у певних юридичних знаннях правової й державної дійсності, формуються на основі повторюваності соціальних, зокрема юридичних, явищ i процесів, що потребують свого впорядкування, урегульованості, задля блага цілого, зокрема державно впорядкованого суспільства. Вони є певним підсумком пізнання реальної державно-юридичної дійсності і становлять певний результат конкретного теоретичного синтезу вже напрацьованих юридичною наукою i використовуваних нею для пізнання зазначеної дійсності понять і категорій» [89, с. 13]. Дослідження кримінальної відповідальності з використанням парності юридичних категорій розкриває нові можливості впливу на суспільні відносини, що $\epsilon$ предметом кримінально-правової охорони (регулювання). Проблема парності покарання і заохочення при реалізації кримінальної відповідальності $є$ маловивченою [90, с. 3; 91, с. 194]. Натомість, дослідження кримінальноправової матерії з цих позицій значно розширюють пізнавальні можливості, розглядають зазначені правові явища у взаємозв'язку i взаємозалежності, повніше фіксують їх внутрішні зв’язки, чіткіше встановлюють як елементи єдності, так і протилежності. О.М. Васильєв зазначає, що «для віднесення юридичних категорій до кола парних категорій необхідно визначити специфічну єдність протилежностей і розкрити їі через відмінність, тотожність, переходи відносно до суттєвого першого, другого i т.д. порядку, що проявляється у роздвоєнні протилежних моментів і сторін» [92, с. 18].

Кримінальні покарання i заохочення $є$ протилежними варіантами реагування держави на правову поведінку. Так, реалізація негативного аспекту 
відповідальності передбачає осуд особи з боку держави та реальні обмеження особистого чи майнового характеру. Покарання, як правило, проявляється у реальному обмеженні прав i свобод засудженого. «Сутністю кримінальної відповідальності як категорії публічного права, - слушно вказує Ю.В. Баулін, - $є$ обмеження прав і свобод злочинця. Така відповідальність існує в трьох аспектах: законодавчому, судовому та виконавчому. Зміст кримінальної відповідальності становить взаємодія трьох її складових елементів - суб’єктів, об’єктів та діяння. Правовою формою законодавчо визначеної кримінальної відповідальності $\epsilon$ санкція кримінально-правової норми, передбаченої КК; індивідуально визначеної судом - обвинувальний вирок суду і реально здійснюваної діяльність органів виконавчої влади, спеціально уповноважених на виконання обвинувального вироку суду» [93, с. 334]. Заохочення ж, навпаки, полягає у різний спосіб мінімізації, передбачених кримінальним законом, обмежень прав i свобод особи. Суспільно-корисна поведінка особи у більшості випадків задовольняє матеріальні і моральні вимоги потерпілого від злочину, прискорює розкриття, посилює ефективність розслідування злочинів та формує притилежну альтернативу традиційним засобам правого впливу у вигляді кримінального покарання.

У загальнотеоретичних дослідженнях немає єдності щодо ознак парності правових категорій. Так, О.В. Малько визначає, що парні юридичні категорії: 1) виражають дуалістичність юридичної інформації; 2) внутрішньо діалектично пов'язані; 3) взаєморегулюють одна одну; 4) визначають у своїй сукупності специфічний баланс мотиваційних правових засобів; 5) є двома узагальнюючими категоріями, що включають основні юридичні засоби у сфері інформаційнопсихологічної дії права [94, с. 110]. Іншої думки з цього питання дотримується В.В. Нирков, що вказує п’ять головних і взаємозалежних ознак цієї взаємодії: 1) єдність протилежностей; 2) їх взаємовиключення та взаємозаперечення; 3) їх співставлення та взаємопроникнення; 4) взаємоперетворення, взаємоперехід протилежностей; 5) нерівноцінність протилежностей у ході взаємодії [95, с. 46]. Не вдаючись до детального аналізу зазначених точок зору, - бо це складна 
філософська проблема, що заслуговує окремого дослідження, зазначимо, що відправною позицією у визначені ознак парних правових категорій $\epsilon$ матеріалістична діалектика та пї «ядро - закон єдності та боротьби протилежностей». Ще один із засновників грецької античної філософії, Геракліт помітив, що все в світі складається $з$ протилежностей Сутність єдності та боротьби протилежностей визначає сенс будь-якої речі, процесу, явища, в тому числі й соціального. Діючи одночасно, ці протилежності утворюють напружений стан, котрим i визначається внутрішня гармонія речі. Геракліт пояснює цю тезу відомим прикладом стрілецького луку: обидва дугоподібних кінці луку намагаються розігнутися, але тятива стягує їх, і ця їхня взаємна напруженість утворює вищу єдність. Боротьба протилежностей є загальною, вона становить справжню справедливість і $є$ умовою існування будь-якої упорядкованої системи. Закон єдності та боротьби протилежностей відображає фундаментальну особливість об’ єктивної дійсності, котра полягає в тому, що всі iї предмети, явища і процеси мають суперечливі моменти тенденції, сторони, що борються і взаємодіють між собою [96]. «Істина протилежностей, - підкреслював Г.В.Ф. Гегель, - полягає лише у їх відношенні одне до одного, тобто, у тому, що кожне з них у самій своїй суті передбачає протилежне» [97, с. 63]. Зміст цього закону влучно окреслив один з фундаторів матеріалістичного вчення Фрідріх Енгельс, який писав, що одна сторона протиріччя так само немислима без іншої, як неможливо мати у руці ціле яблуко після того, як з'їдена його половина [98, с. 70]. Покарання і заохочення як протилежні сторони реалізації кримінальної відповідальності характеризуються, на наш погляд, взаємозв’язком та взаємозалежністю, які проявляються безпосередньо у їх: а) взаємній єдності; б) взаємовиключенні; в) взаємопроникненні; г) взаємопереході у інші порядки правових категорій. Розглядаючи в цьому дослідженні парність кримінальних покарання і заохочення ми будемо виходити саме із вищевказаної послідовності їх взаємозв’язків та взаємозалежностей.

Взаємна єдність покарання і заохочення полягає у тому, що, по-перше, вони існують у рамках кримінального законодавства як єдиної, публічної, 
охоронної галузі законодавства України; по-друге, покликані забезпечувати єдине для обох завдання правового забезпечення охорони прав і свобод людини i громадянина, власності, громадського порядку та громадської безпеки, довкілля, конституційного устрою України від злочинних посягань, а також запобігання злочинам; по-третє, пронизані єдиними галузевими принципами законності, справедливості, гуманізму, особистої, винної відповідальності, індивідуалізації відповідальності та покарання тощо; вчетверте, виступають у якості регуляторів єдиної системи суспільних відносин, що виникають у зв'язку iз вчиненням злочинів та суспільно-небезпечних посягань. Природно, що пріоритет у справі охорони суспільних відносин кримінально-правовими засобами віддається переважно формі реалізації негативної кримінальної відповідальності у вигляді покарання. Має рацію В.Я. Тацій, коли зазначає, що предметом кримінально-правового регулювання виступають насамперед ті суспільні відносини, які виникають у зв'язку з вчиненням злочину [99, с. 108]. Проте, на нашу думку, зводити об'єкт регулювання кримінального права тільки до суспільних відносин, що виникають 3 зв'язку із вчиненням злочинів $\epsilon$ односторонньою i неповною позицією. Законодавець має точно і повно визначити межі правомірного та неправомірного, тим самим створити умови для правильного застосування кримінального закону.

I.Е. Звечаровський заперечує парність покарання і заохочення виходячи 3 того, що заохочення протистоїть відповідальності та визнає їх однопорядковими структурними елементами стимулювання. «Заохочення, - наголошує цей дослідник, - $\epsilon$ закономірним наслідком юридичної оцінки позитивновідповідальної правової поведінки. На рівні держави, як суб'єкта відношення відповідальної залежності, заохочення - це і $є$ позитивна відповідальність (відповідь), так само як покарання - одна 3 форм прояву негативної відповідальності» [100, с. 112]. Близьку думку висловлює й В.М. Баранов, котрий вважає, що стимулювання є одним із тих діалектичних понять, яке виражає тотожність, охоплює єдність двох відносних протилежностей - заохочення $\mathrm{i}$ відповідальності. Якщо відповідальність $є$ негативною стороною методу 
стимулювання, то заохочення представляє його позитивну сторону [101, с. 6]. Зазначена точка зору здається занадто категоричною. Заохочення і покарання $\epsilon$ основними елементами правового впливу задля правомірної, суспільносхвальної поведінки, але для досягнення цієї мети використовують протилежні засоби правового впливу на свідомість i волю особи. Покарання на психологічному рівні діє як «певний бар’єр», правова заборона вчинення суспільно-небезпечних дій та має стримувати вплив негативних мотивівспонукань особи. Заохочення, навпаки, має збуджувати, активувати позитивні спонукання, які об’єктивуються у правомірних вчинках.

Взаємовиключення покарання i заохочення полягає, по-перше, у протилежних 3 боку суспільної цінності та оцінки фактичних та правових підставах їх застосування, по-друге, у неспівпадінні соціального та правового змісту їх сутності, по-трете, у різних правових підставах та наслідках застосування у кримінальному праві, вчетверте, у якості регуляторів протилежних систем виступають різні методи. Соціальна сутність покарання i заохочення $\epsilon$ протилежною. В.С. Трахтеров у якості обов'язкової ознаки кримінального покарання зазначав правову і моральну оцінку у вигляді осуду 3 боку держави [102, с. 3]. Реалізація негативного аспекту кримінальної відповідальності у будь-якій формі завжди пов’язана з негативною оцінкою вчиненого злочину з боку держави у вигляді осуду, що знаходить своє закріплення у обвинувальному вироку суду. Навіть найбільш поблажлива форма - «це обмеження особи, винної в учиненні злочину, у праві на «добре ім’я», тобто обмеження їі гідності» [93, с. 341]. У п. 1 постанови Пленуму ВСУ від 24 жовтня 2003 р. № 7 «Про практику призначення судами України кримінального покарання» зазначено, що призначаючи покарання, у кожному конкретному випадку суди зобов’ язані враховувати ступінь тяжкості вчиненого злочину, дані про особу винного та обставини справи, що пом'якшують чи обтяжують покарання. Особі, яка вчинила злочин, має бути призначене покарання, необхідне й достатнє для іï виправлення та попередження нових злочинів [103]. Навпаки, заохочення правомірної суспільно-корисної поведінки є державним 
схваленням. Заохочення передбачає як схвальну оцінку поведінки особи, так i зміну ставлення до особи з осуду на схвалення у разі вчинення нею правомірної поведінки. Так, скажімо схваленню підлягає поведінка, що не має і не може мати суспільно-небезпечного характеру та спрямована, як правило, на припинення суспільно-небезпечної (неправомірної) поведінки інших осіб (необхідна оборона, затримання злочинця, виконання спеціального завдання тощо). В преамбулі до постанови Пленуму ВСУ від 26 квітня 2002 р. № 1 «Про судову практику у справах про необхідну оборону» зазначається, що право кожного на необхідну оборону від суспільно-небезпечного посягання є важливою гарантією реалізації конституційних положень про непорушність прав і свобод людини i громадянина, про невід’ємне право кожної людини на життя, недоторканність іiі житла й майна, а також забезпечує умови для захисту суспільних інтересів та інтересів держави [104].

Своєрідне схвалення також передбачається у разі позитивної посткримінальної поведінки при закінченому злочині. Заохочення у цих випадках $\epsilon$ «актом прощення винної особи» в силу зникнення чи суттєвого Зниження суспільної небезпеки особи, яка його вчинила. В Загальній частині КК звільнення особи від кримінальної відповідальності має місце у зв’язку: 3 дійовим каяттям (ст. 45 КК); 3 примиренням винного 3 потерпілим (ст. 46 КК); 3 передачею особи на поруки (ст. 47 КК); із зміною обстановки (ст. 48 КК); із закінченням строків давності (ст. 49 КК); неповнолітнього із застосуванням примусових заходів виховного характеру (ч. 1 ст. 97 КК). Основна суспільна спрямованість полягає у психологічному впливі, спонуканні винних, у тому числі неповнолітніх осіб, які вперше вчинили злочини невеликої тяжкості або необережні злочини середньої тяжкості, крім корупційних злочинів, до щирого каяття, активного сприяння розкриттю злочину, повного відшкодування завданих ними збитків або усунення заподіяної шкоди, примирення із потерпілим, не ухилятися від заходів виховного характеру та не порушувати громадського порядку тощо. В Особливій частині кримінального права правомірна посткримінальна поведінка э підставою спеціального звільнення від 
кримінальної відповідальності у: ч. 2 ст. 111, ч. 2 ст. 114, ч. 3 ст. 175, ч. 4 ст. 212 , ч. 4 ст. $212-1$, ч. 2 ст. 255 , ч. 2 ст. $258-3$, ч. 4 ст. $258-5$, ч. 6 ст. 260 , ч. 3 ст. 263 , ч. 4 ст. 265 , ч. 4 ст. 289 , ч. 4 ст. 307 , ч. 4 ст. 309 , ч. 4 ст. 311 , ч. 5 ст. 321 , ч. 4 ст. 321 1, ч. 5 ст. 354, ч. 4 ст. 401 КК. 3 позицій запобігання злочинам заохочувальні норми поділяються на такі, що спрямовані: 1) на припинення злочину, самовикриття і викриття інших осіб винних у його вчиненні, активне сприяння розкриттю злочину (ч. 2 ст. 111, ч. 2 ст. 114, ч. 2 ст. 255, ч. 2 ст. 258-3, ч. 4 ст. 258-5, ч. 6 ст. 260 , ч. 4 ст. 289 , ч. 4 ст. 309 , ч. 5 ст. 321 , ч. 5 ст. 354 КК); 2) на виключення 3 обігу предметів, засобів, речовин, що становлять підвищену суспільну небезпеку (ч. 3 ст. 263 , ч. 4 ст. 307 , ч. 4 ст. 311 , ч. 5 ст. 321 , ч. 4 ст. 321 1 КК); 3) на повернення майна, здобутого злочинним шляхом, або на відшкодування завданих збитків (ч. 3 ст. 175, ч. 4 ст. 212, ч. 4 ст. 212-1, ч. 4 ст. 289 KК).

Зовнішній вплив на волю і свідомість суб'єктів кримінально-правових відносин носить різний характер, але в цілому зводиться до двох основних методів: імперативних приписів, реалізація котрих забезпечується застосуванням заходів примусу та диспозитивних норм, що спонукають до правомірної, суспільно-корисної поведінки. Метод заохочення суспільно-корисної поведінки виступає найпотужнішим стимулюючим фактором, що сильніше за інших, формує зацікавленість суб'єктів у позитивній поведінці, створюючи для неї режим найбільшого сприяння. Сутність правових стимулів та обмежень найбільш рельєфно відбивається у парності покарання і заохочення. Правові стимули розглядаються разом з правовими обмеженнями у зв'язку з тим, що вони виступають у якості парних юридичних категорій, які внутрішне діалектично пов'язані та взаємно обумовлюють одне одного в процесі правового регулювання. Основою методу заохочення $є$ добровільність невимушеність суспільно-корисної поведінки. Цей метод надає можливість вибору з декількох варіантів правомірного, бажаного варіанту поведінки та стимулює іiї шляхом виключення, звільнення або пом'якшення реального або потенційного кримінально-правового обтяження. Метод заохочення у кримінальному 
законодавстві окреслює такі моделі поведінки, що заслуговують позитивної суспільної оцінки. В цих моделях органічно поєднуються суспільні, державні і особисті потреби та інтереси, що приводить до взаємоприйнятного результату. Безумовно, суспільство зацікавлене у виконанні усіма громадянами кримінальноправових заборон, чим у значній мірі забезпечується правовий режим законності. Проте, якщо хтось вчинює злочин, держава встановлює заохочувальній припис, модель суспільно-корисної поведінки особи, що з власної волі не доводить злочин до кінця та супроводжує його звільненням особи від кримінальної відповідальності, якщо фактично вчинене діяння не містить складу іншого злочину (ст. 17 КК). Законодавець правовим заохоченням прагне забезпечити повне, всебічне поєднання суспільних і особистих інтересів у сфері кримінальноправового регулювання, яке б передусім, спрямовувалось на запобігання (попередження) злочинів.

Правові підстави та наслідки застосування покарання і заохочення $\epsilon$ взаємовиключними. Покарання породжує судимість як правовий наслідок. За авторським визначенням В.В. Голіни, судимість особи - це іiі правовий стан, створений реалізацією кримінальної відповідальності, що виникає внаслідок засудження іï обвинувальним вироком суду за вчинений нею злочин до будьякого покарання, який (стан) виступає підставою для державного осуду i застосування до особи передбачених законом протягом певного, установленого законом перебігу часу, обмежень та втрат і відіграє у системі кримінальноправових засобів роль сприяючого фактору досягнення і закріплення цілей покарання [105, с. 310]. Заохочення, навпаки, у формі, скажімо, звільнення від кримінальної відповідальності на підставах Загальної та Особливої частин КК передбачає одним 3 юридичних наслідків те, що факт вчинення злочину втрачає будь-яке кримінально-правове значення.

Взаємопроникнення покарання і заохочення діалектично неминуче. Про це свідчать елементи схвалення, що можуть існувати у покаранні та осуду у заохоченні. Так, у обвинувальному вироку суду, яким призначається покарання, за наявності обставин, що пом'якшують кримінальне покарання, суд повинен 
призначити покарання більш м'яке, ближче до нижньої межі або перейти до більш м'якого покарання, що не передбачене санкцією статті Особливої частини КК. Водночас, особа може зазнати осуду з боку держави у вигляді покарання, якщо у фактично вчиненому є ознаки іншого складу злочину при добровільній відмові (ч. 2 ст. 17 КК); при умисному заподіянні тому, хто посягає, тяжкої шкоди, яка явно не відповідає небезпечності посягання або обстановці захисту при необхідній обороні (ч. 3 ст. 36 КК); при умисному заподіянні особі, що вчинила злочин, тяжкої шкоди, яка явно не відповідає небезпечності посягання або обстановці затримання злочинця (ч. 2 ст. 38 КК) та ін. Взаємні переходи в інші порядки досліджуваних правових категорій спостерігається як у низхідному та і висхідному напрямках. Найбільш узагальнені соціальні категорії, що кореспондуються 3 заохоченням та покаранням, це методи соціального управління - переконання та примус. Переконання як метод соціального впливу на свідомість людей покликане без примусу схиляти до відповідної поведінки особу, що відповідає іï волевиявленню, розширяти свободу вибору варіантів поведінки. Воно знаходить свій прояв у вигляді психічного впливу, у процесі якого особа добровільно схиляється до громадської думки, свідомо привласнює цю думку як особисту цінність, із розумінням ставиться до неї, а також до такої поведінки, котра цій думці, відповідає. Примус - це метод, що передбачає примушення до відповідної поведінки засобами силового тиску, всупереч волевиявленню, звужуючи свободи вибору особи. Г.В.Ф. Гегель зазначав, що в людині можливо примусити чи підкорити тільки їі фізичну, зовнішню сторону, але воля людини, яка завжди вільна в собі й для себе не може зазнати примусу, хіба лише, якщо вона сама не відступить від фізичної, зовнішньої сторони, в якій iii тримають або уявляють, що тримають [106, с. 91]. Методи примусу i переконання є універсальними, такими що притаманні будь-якій регулятивній системі: звичаям, традиціям, моралі, у тому числі й праву. На побутовому рівні взаємопереходи заохочення та покарання спостерігається у впливі на поведінку людей таких найдавніших засобів як «батіг та пряник». Стародавній китайський філософ Конфуцій надавав велике значення політиці «батога й пряника» в 
управлінні державою. «Державний батіг - «лі», - вважав Конфуцій, - $є$ наріжним каменем соціальної організації суспільства, без «лі» не може бути порядку, а, отже, процвітання у державі: немає «лі» - немає різниці між государем i підданими, верхами і низами, старими і молодими. Лі встановлює порядок речей» [107]. Відтак, покарання і заохочення виступають парними правовими категоріями, що комбінуються як діалектичні єдності й протилежності, взаємозаперечують та взаємозумовлюють одне одного у реалізації кримінальної відповідальності. Засоби покарання і заохочення прямо передбачаються в кримінально-правових нормах як протилежні юридичні наслідки протиправної або правомірної поведінки. 